\title{
The Chelsea Critical Care Physical Assessment Tool (CPAx): validation of an innovative new tool to measure physical morbidity in the general adult critical care population; an observational proof-of-concept pilot study
}

\author{
E.J. Corner ${ }^{\mathrm{a}, *}$, H. Wood $^{\text {a }}$, C. Englebretsen ${ }^{\mathrm{a}}$, A. Thomas ${ }^{\mathrm{b}}$, R.L. Grant ${ }^{\mathrm{c}, \mathrm{d}}$, \\ D. Nikoletou ${ }^{\mathrm{c}, \mathrm{d}}, \mathrm{N}$. Soni ${ }^{\mathrm{a}}$ \\ ${ }^{a}$ Chelsea and Westminster NHS Foundation Trust, 369 Fulham Road, London SW10 9NH, UK \\ b The Royal London Hospital, Barts and The London NHS Trust, London, UK \\ ${ }^{\mathrm{c}}$ Faculty of Health and Social Care Sciences, Kingston University, Kingston, UK \\ d St. George's Hospital Medical School, University of London, London, UK
}

\begin{abstract}
Objective To develop a scoring system to measure physical morbidity in critical care - the Chelsea Critical Care Physical Assessment Tool (CPAx).

Method The development process was iterative involving content validity indices (CVI), a focus group and an observational study of 33 patients to test construct validity against the Medical Research Council score for muscle strength, peak cough flow, Australian Therapy Outcome Measures score, Glasgow Coma Scale score, Bloomsbury sedation score, Sequential Organ Failure Assessment score, Short Form 36 (SF-36) score, days of mechanical ventilation and inter-rater reliability.

Participants Trauma and general critical care patients from two London teaching hospitals.

Results Users of the CPAx felt that it possessed content validity, giving a final CVI of $1.00(P<0.05)$. Construct validation data showed moderate to strong significant correlations between the CPAx score and all secondary measures, apart from the mental component of the SF-36 which demonstrated weak correlation with the CPAx score $(r=0.024, P=0.720)$. Reliability testing showed internal consistency of $\alpha=0.798$ and inter-rater reliability of $\kappa=0.988$ (95\% confidence interval 0.791 to 1.000 ) between five raters.

Conclusion This pilot work supports proof of concept of the CPAx as a measure of physical morbidity in the critical care population, and is a cogent argument for further investigation of the scoring system.
\end{abstract}

(C) 2012 Chartered Society of Physiotherapy. Published by Elsevier Ltd. All rights reserved.

Keywords: Rehabilitation; Critical illness; Physiotherapy; Muscular diseases; Outcome assessment

\section{Introduction}

Critical illness frequently results in impaired neuromuscular function and hence debilitation [1-4]. This phenomenon is commonly known as intensive care unit acquired weakness (ICU-AW).

In March 2009, the UK National Institute for Health and Clinical Excellence (NICE) introduced Clinical Guideline 83 (CG83), entitled 'Rehabilitation after critical illness', which aims to optimise the management of ICU-AW [5]. It

\footnotetext{
* Corresponding author. Tel.: +0208 7465689; fax: +0208 8466069.

E-mail address: evelyn.corner@ chelwest.nhs.uk (E.J. Corner).
}

recommends early identification of patients at risk of physical morbidity by regular short clinical assessments at intervals throughout the patient's hospital stay. Once identified as 'at risk', a comprehensive physical assessment should be completed, and a structured patient-specific rehabilitation programme commenced. Progress should be monitored using patient-agreed goals and should be reviewed regularly.

NICE CG83 was a long-awaited guideline and a milestone in the management of ICU-AW. However, the document highlights the lack of validated assessment tools and paucity of evidence-based rehabilitation practices in the critically ill population. For example, Section 2.1 (p. 23) of CG83 focuses on identifying screening and assessment tools to assess 
physical morbidity. Only one research article [6] was considered to be sufficiently scientifically robust for inclusion; this looked at the Rivermead Motor Index and even this 'should be interpreted with caution due to its ill-defined inclusion criteria and small population'. The lack of a validated assessment tool poses a significant obstacle to the practical application of CG83, preventing its implementation in a standardised manner at a national level. Further implications include the lack of an objective marker for standardisation of patient management and health economic assessment. It also has implications in the research setting.

The most commonly accepted scoring system for the assessment of muscle function is the Medical Research Council (MRC) score for muscle strength [7]. This score looks solely at strength, and as patients may learn to be functional in the absence of strength, its generalisability and validity for measuring physical morbidity is questionable. More importantly, it is time consuming and relies on a degree of co-operation and cognitive function. From the patient perspective, it may be considered relatively abstract and difficult to interpret. Other measures that have been trialled, such as the Barthel Index and the Functional Independence Measure, lack sensitivity in patients with low levels of function, and/or they have not been validated or reliability tested in a critically ill population $[8,9]$.

The most realistic attempts to address the lack of validated assessment tools in critical care are the Physical Functional ICU Test (PFIT) [10] and the University of Rochester Acute Care Evaluation (URACE) [11]. The PFIT relies on the patient being able to stand up from a chair and march on the spot. These tasks may be difficult for patients in the acute phases of critical illness, and published results only exist for a very small sample size $(n=13)$. The URACE is a scoring system that grades people's independence with bed mobility, transfers (bed to chair), locomotion and stairs. It has not been tested for reliability and validity, and no patient data have been published to date. It was also developed with input from clinicians at a single hospital site in the USA; thus, its generalisability is questionable.

There is an obvious and urgent need for a practical, holistic and reproducible bedside measure of physical morbidity. This could facilitate patient assessment, highlighting problem areas and guiding rehabilitation; help to monitor progress; and form an objective measurement that is intelligible between clinical specialties and service users.

The aim of this pilot study was to develop a bedside scoring system to grade physical morbidity in the critical care population - the Chelsea Critical Care Physical Assessment Tool (CPAx).

\section{Methods}

This study involved several stages. For clarity, this paper is presented with the method followed by the results for each stage in order of completion.
The CPAx was developed using a pragmatic iterative process recommended by Streiner and Norman [12] and mimicking a modified Delphi technique (Fig. 1, see online supplementary material). The final version of the CPAx is shown in Appendix 1.

Supplementary material related to this article found, in the online version, at doi:10.1016/j.physio.2012.01.003.

\section{Stage 1. Initial development of the CPAx}

The CPAx was initially designed as a pictorial composite of 10 commonly assessed components of physical ability, each graded on a six-point Guttman scale from complete dependence to independence. The initial working draft was reviewed internally by clinicians (medics, nurses and therapists), and trialled informally within the critical care unit (CCU). The feedback was used to modify the CPAx draft. This was repeated seven times to produce a final working version.

\section{Stage 2. Focus group}

The next stage was a focus group with a purposive sample of seven [including six clinical specialist/lead (Band 8a)] physiotherapists in critical care and acute rehabilitation from four London hospitals and the primary developer. A Band 8a physiotherapist has highly developed specialist knowledge and skills, and leads in a specialist clinical area, clinical audit and research [13]. In total, the participants had 87 years of postgraduate experience, one postgraduate certificate, three master's degrees, and one $\mathrm{PhD}$ in progress.

The aim of the focus group was to further develop the CPAx and assess its face and content validity. The focus group was recorded and transcribed verbatim, and the principles of thematic content analysis were applied to justify subsequent changes.

Table 1 summarises the focus group transcript, listing and justifying the components of the CPAx.

Prior to the focus group, attendees reviewed the CPAx and completed a Likert scale questionnaire to establish a content validity index (CVI) [14,15]; a measure of the proportion of experts endorsing the CPAx (Appendix 2, see online supplementary material). Each question was scored out of four, and a score of three or more for each component indicated that the expert endorsed that component. The CVI was equated by dividing the number of experts endorsing the tool by the total number of experts. It was piloted on one physiotherapist, whose data were not included in the study results. Following the focus group, the CVI questionnaire was repeated with reference to the modified version of the CPAx, which was used as a method of respondent validation and considered the outcome of the focus group.

Supplementary material related to this article found, in the online version, at doi:10.1016/j.physio.2012.01.003. 
Table 1

Focus group summary including components of the Chelsea Critical Care Physical Assessment Tool (CPAx) and rationale for their inclusion.

\begin{tabular}{ll}
\hline Component of physicality & Description \\
\hline Respiratory function & $\begin{array}{l}\text { Amount of respiratory support required, in terms of } \\
\text { both ventilation and oxygenation }\end{array}$
\end{tabular}

Rationale for inclusion

ICU-AW weakness is commonly associated with prolonged weaning from mechanical ventilation and impaired cough function due to respiratory muscle atrophy [25]. Inclusion of the cough and respiratory function sections therefore gives a much more holistic impression of the patient's physical problems associated with ICU-AW

Cough

Bed mobility
Cough effectiveness, in terms of consistency and secretion clearance

The ability and level of assistance required to move around the bed
Supine to sitting on the edge of the bed

Dynamic sitting

Sit to stand

Standing balance

Transferring from bed to chair

Stepping

Grip strength
The ability and level of assistance required to sit on the edge of the bed from supine

The level of support required to maintain sitting balance, progressing to the ability to reach out of the base of support

The ability and level of assistance needed to stand from a sitting position of $>90^{\circ}$ of knee flexion The amount of support required to maintain standing, ranging from a tilt table to independent Mode of transfer from bed to chair (e.g. cradle hoist transfers, standing hoist, independent, etc.)

Assesses the physical ability to walk, and support required (e.g. frame, physical assistance, etc.) Grip strength measured by a grip dynamometer as a percentage of expected, when age and gender corrected
All physical tasks with composite parts of measurement scales and knowledge of the functional impairment commonly associated with ICU-AW. As the purpose of the CPAx is not only to measure physical ability but also to act as an outcome measure for physiotherapy research, it was important to include components that would be influenced by physiotherapy treatment

Grip strength has been shown to accurately reflect whole-body strength and has also been used as a diagnostic tool for ICU-AW [19]

ICU-AW, intensive care unit acquired weakness.

\section{Stage 2. Results}

The pre focus group CVI was $0.67(P>0.05)$ and the post focus group CVI was $0.83(P<0.05)$, indicating that the CPAx was considered, by a small number of specialist clinicians, to be content valid.

\section{Stage 3. CVI questionnaire}

To further explore the content validity of the CPAx, it was distributed for use across three UK teaching hospitals. Following a minimum 3-month trial, the CVI questionnaire was sent out to all physiotherapists who had been using the tool regularly $(n=14)$; clinicians included in the development of the tool were excluded.

\section{Stage 3. Results}

Fourteen clinicians responded to the questionnaire and all of them rated the tool as content valid, giving a final CVI of $1.00(P<0.05)$.

\section{Stage 4. Observational cohort study}

\section{Study design}

This was a prospective cohort study of general and trauma CCU patients admitted to Chelsea and Westminster NHS Foundation Trust and the Royal London Hospital NHS Trust between June and August 2010. Following recruitment, all participants were assessed by a physiotherapist who used the CPAx on admission, discharge and every Monday, Wednesday and Friday for the duration of their CCU stay. One retrospective CPAx score was collected as a measure of premorbid physical level (this excluded the grip strength component). The scores were blinded to the researcher who collected further data (listed below) to test the construct validity of the CPAx. These measures were taken on the same day as each CPAx score:

- Peak cough flow;

- Australian Therapy Outcome Measures (AusTOMs) score;

- Medical Research Council (MRC) score for quadriceps and biceps strength; 
- Sequential Organ Failure Assessment (SOFA) score;

- Bloomsbury sedation scale (scores -3 to 1 );

- Glasgow Coma Scale (GCS) score;

- Number of days of mechanical ventilation; and

- Short Form 36 (SF-36) score.

As all of the above measures were taken by the researcher, no inter-rater reliability testing was required.

\section{Construct validation}

A series of null hypotheses were constructed to ascertain correlations between the CPAx and other variables measuring the 'physical morbidity' construct.

Peak cough flow. Peak cough flow was compared with the cough component of the CPAx, as it is an objective measure of cough strength [16]. Patients that could be disconnected from the ventilator (as determined by the clinical team) had their peak cough flow measured using either a calibrated Vitalograph Spirometer 2120 (Vitalograph, Buckingham, UK) or a calibrated Microplus Spirometer (Micro Medical Ltd, Cardinal Health, Basingstoke, UK). Due to infection policy and financial reasons, it was not possible to standardise equipment between sites.

If the patient could not be disconnected from the ventilator, the expiratory flow wave form on the ventilator was used to measure peak cough flow. An Evita XL ventilator (Dräger, Telford, PA, USA) was used at the lead site, and an Engstrom Carestation ventilator (GE Healthcare, Hatfield, UK) was used at the second site.

Peak cough flow was measured in a standardised seated position (i.e. $90^{\circ}$ of knee flexion and hip flexion). Patients were given one practice trial followed by one measurement per session. All measurements were taken during spontaneous coughing. If it was clinically inappropriate to measure peak cough flow, the measurement was not taken. It is accepted that the validity of the peak cough flow measurement may be affected by different assessment techniques.

The remaining measures were compared with the total CPAx score.

AusTOMs score. The AusTOMs is a generic Australian therapy outcome measure $[17,18]$ that grades patients on a Guttman scale (0 to 5) from complete dependence to independence. To standardise the measurements, the activity limitation and impairment sections of both the balance and postural control component and the musculoskeletal component of the AusTOMs were chosen for assessment.

The AusTOMs comparator was selected because it was being used at both sites already, and is a simple measure that can be graded easily by the researcher. The physiotherapy section of the AusTOMs has also demonstrated both face and content validity [17].

Quadriceps and biceps muscle strength (MRC score). The MRC score is a six-point scoring system (0 to 5) that grades muscle function from no muscle activity to full strength. The MRC score was selected as it is one of the most common objective measurement scales used by physiotherapists on the CCU, as well as a diagnostic tool for ICU-AW [19]. Biceps and quadriceps muscle strength were chosen as they are key anti-gravity muscles necessary for functional tasks, and completing a whole-body strength test would have been impractical $[19,20]$. For analysis, these scores were compared in isolation and as a total out of 20.

The measurements were taken in a seated position (either in the electric bed or in the chair). Participants were asked to resist the researcher from moving the limb. The limb was then graded on the scale, and data were recorded. If the participant was unable to follow commands, no score was given; however, if they were sedated, they scored 0 .

SOFA score. The SOFA score was chosen as a comparator as greater acuity of illness means a greater likelihood of prolonged bed rest, and possibly more sedation and neuromuscular blocking agents, increasing the risk of ICU-AW $[2,4]$.

GCS and Bloomsbury sedation scale scores. The CPAx was developed to be responsive from complete dependence to independence, and thus needed to be validated throughout its entirety. Other scores of physical morbidity have a significant floor effect in the CCU population, and therefore would be poor comparators to the CPAx in the low-functioning patient. As a result, both GCS and sedation scores were selected as comparators. It was anticipated that both the GCS and sedation scores would only be comparable with the CPAx at the lower end of the CPAx scale. Sedation scores of 1 to -3 were chosen to allow correlation analysis by ensuring a linear relationship between the two measures.

Number of days of mechanical ventilation. A longer time on mechanical ventilation is associated with poorer functional outcome from critical illness [21]. Therefore, length of time on mechanical ventilation was compared with the CCU discharge CPAx score.

SF-36 score. The SF-36 is a validated health-related quality-of-life questionnaire [22]. It is separated into two components: physical and mental. SF-36 scores were collected to compare with the pre-admission CPAx scores. Furthermore, as recovery from critical illness is associated with pre-admission health status [23,24], the SF-36 score was also compared with the CCU discharge CPAx score.

All statistical analyses were performed using Statistical Package for the Social Sciences Version 16.0 (SPSS, IBM Corporation, NY, USA). Spearman's rank correlation coefficient was used to analyse the construct validity of the CPAx against the MRC score, SOFA score, AusTOMs score, sedation score, GCS score and peak cough flow, as data were skewed. One randomly selected time point for each participant was used in the correlation analysis, giving a total of 
Table 3

Construct validity results summary: Spearman's rank correlation coefficients between Chelsea Critical Care Physical Assessment Tool (CPAx) scores and each comparator.

\begin{tabular}{|c|c|c|}
\hline Comparator & $R$ & $P$-value \\
\hline Peak cough flow & 0.633 & 0.006 \\
\hline AusTOMs MSK score (activity) & 0.735 & $<0.001$ \\
\hline AusTOMs MSK score impairment & 0.763 & $<0.001$ \\
\hline AusTOMs BPC score (activity) & 0.903 & $<0.001$ \\
\hline AusTOMs BPC score (impairment) & 0.874 & $<0.001$ \\
\hline MRC score (right biceps) & 0.693 & $<0.001$ \\
\hline MRC score (left biceps) & 0.640 & $<0.001$ \\
\hline MRC score (right quads) & 0.697 & $<0.001$ \\
\hline MRC score (left quads) & 0.673 & $<0.001$ \\
\hline MRC total score & 0.650 & $<0.001$ \\
\hline SOFA score & -0.683 & $<0.001$ \\
\hline GCS score & 0.764 & $<0.001$ \\
\hline Bloomsbury sedation scale score $(-3$ to 1$)$ & 0.420 & 0.036 \\
\hline Days of mechanical ventilation & -0.506 & $<0.01$ \\
\hline SF-36 (physical component) and pre-admission CPAx score & 0.720 & 0.013 \\
\hline SF-36 (mental component) and pre-admission CPAx score & 0.122 & 0.720 \\
\hline SF-36 (mental component) and discharge CPAx score & 0.024 & 0.954 \\
\hline SF-36 (physical component) and discharge CPAx score & 0.843 & 0.009 \\
\hline
\end{tabular}

AusTOMs, Australian Therapy Outcome Measures; MSK, musculoskeletal; BPC, balance and postural control; MRC, Medical Research Council; SOFA, Sequential Organ Failure Assessment; GCS, Glasgow Coma Scale; SF-36, Short Form 36.

33 for each measure. This was because each individual participant's scores could naturally correlate with themselves. Randomly analysing one time point for each participant eliminated this risk.

\section{Inter-rater reliability}

Five physiotherapists each assessed three patients selected at random. The patient's lead physiotherapist carried out the assessment, which was observed by four other physiotherapists. The lead physiotherapist did not verbalise any of their assessment to the observers. Each physiotherapist then scored the patient in isolation. All assessors were blinded to the other scores. Intraclass correlation coefficients between each component of the CPAx, as well as the total score, were equated.

Diagnosis, medication, age, past medical history, APACHE II scores and outcome data were collected for demographic purposes.

\section{Study population}

A sample size calculation was completed for a Pearson's correlation with a two-sided test, alpha $=0.05$ and a power of $80 \%(1-\beta)$. At least 26 participants were required to find a statistically significant correlation of above 0.5 between MRC score and CPAx score. Thirty-three participants were recruited to account for attrition.

\section{Exclusion criteria}

The purpose of the CPAx score was to fill the void in the assessment of CCU patients in conjunction with NICE CG83, which is aimed at patients who do not fall under specialist rehabilitation services. Therefore, cardiothoracic and burns patients, and patients admitted with a focal neurology causing functional deficit were excluded. The remaining exclusion criteria were: expected length of stay $<48 \mathrm{~h}$ (to eliminate routine postoperative admissions), unable to achieve consent, pregnancy, and if it was deemed inappropriate by the clinical team.

\section{Stage 4. Results}

\section{Participant characteristics}

Seventy-six patients were identified for recruitment into the study. Forty-three prospective participants either declined, died, transferred out of the unit, or their clinical picture changed making them inappropriate for the study. Thirty-three participants were recruited. Participant attrition and the consent procedure is displayed in Fig. 2 (see online supplementary material). The baseline demographics for these participants are shown in Table 2 (see online supplementary material).

Supplementary material related to this article found, in the online version, at doi:10.1016/j.physio.2012.01.003.

\section{Construct validity}

One hundred and ninety-two CPAx scores were collected, with a mean of six scores per patient. Peak cough flow was measured successfully on $58 \%$ of occasions $(n=82)$. Reasons for not measuring peak cough flow were unable to cough, sedated, on high-frequency oscillatory ventilation or refusal. MRC score was measured successfully on $80 \%$ of occasions $(n=129)$. Reasons for not measuring MRC score were inability to follow commands/drowsiness or refusal. All other measures were recorded successfully. 
Spearman's rank correlation coefficient analysis demonstrated moderate to strong significant positive correlations between the CPAx score and the MRC score, GCS score, sedation score -3 to 1 , peak cough flow and AusTOMs score. There was a significant positive correlation between pre-admission CPAx score/CCU discharge CPAx score, and the physical component of the SF-36, but no correlation with the mental component of the SF-36. There was a significant negative correlation between CPAx score and SOFA score, and CCU discharge CPAx score and the number of days of mechanical ventilation. A summary of these statistics is presented in Table 3.

\section{Reliability}

Inter-rater reliability and internal consistency (Cronbach's alpha) were strong at $\kappa=0.988$ (95\% confidence interval 0.791 to $1.000 ; P<0.01)$ and $\alpha=0.798$, respectively. A summary of the intraclass correlation coefficients for inter-rater reliability is presented in Table 4 (see online supplementary material).

Supplementary material related to this article found, in the online version, at doi:10.1016/j.physio.2012.01.003.

\section{Discussion}

The CPAx score demonstrated moderate to strong significant positive correlations with GCS score, sedation score (-3 to 1), muscle strength, AusTOMs score, SF-36 (physical component) score and peak cough flow. It also demonstrated a significant negative correlation with SOFA score and the number of days of mechanical ventilation. These results combined suggest validity in the assessment of overall physical morbidity.

Equally importantly, the CPAx score has been endorsed by physiotherapists reviewing and using the tool clinically, and has been shown to have good inter-rater reliability, albeit in a small number of patients. Internal consistency is strong, suggesting that the CPAx can be used consistently with minimal observer error by physiotherapists of varied experience. However, reliability testing in a larger sample would be beneficial.

The CPAx assesses (directly or indirectly) all of the components of physical morbidity identified as important by a panel of experts. This tool is unique in its inclusion of respiratory domains. In the critically ill, respiratory function and, in particular, weaning from mechanical ventilation is an important component of early rehabilitation [25]. The CPAx allows holistic assessment in the critically ill population, but also helps to limit any floor effect, as observed in other tools of this nature (e.g. the Barthel Index). The authors believe that the CPAx possesses some of the essential psychometric properties of a measurement scale.
There has been no attempt to weight the components of the CPAx. Weighting would make the CPAx psychometrically stronger, but at the expense of simple, quick administration and hence clinical utility. A psychometrically strong assessment that is never used due to complex administration is futile. Furthermore, as the CPAx spans the continuum from dependence to independence, the importance of each component will differ depending on the recovery stage. What is clinically significant in the acute stages of illness will differ with rehabilitation stage. Therefore, weighting would be difficult, if not impossible. The consequence is that the CPAx is appropriately regarded as an ordinal scale.

\section{Limitations}

In this report, the sample size is limited, both in the focus group and the cohort study. There was an insignificant correlation between CPAx score and the mental component of the SF-36. As the CPAx is designed to assess physical morbidity, the non-significant correlation with mental health status is unsurprising.

The CPAx was developed in London, so generalisability may be limited. Further assessment in other centres is required, but it is thought unlikely that the components of the tool would be substantially different elsewhere. This is a pilot study completed as part of a master's degree; as such, it was confined by time and finances.

\section{Conclusion}

This preliminary work demonstrates proof of concept of the CPAx. As a pilot study, it provides a cogent argument for investigating this assessment system further in large multicentre studies. Future work should focus on clinician and patient perceptions of the CPAx, further reliability testing, expert review of the CPAx, and predictive validity for hospital outcome.

\section{Acknowledgements}

The authors would like to acknowledge the input of those involved in the development of the CPAx: Ms. Bronwen Connolly, Mr. Gareth Jones, Ms. Alex Curtis; and the support of the clinical teams at the Chelsea and Westminster NHS Foundation Trust, the Royal London Hospital and St George's University of London.

Ethical approval: Camden and Islington Research Ethics Committee (Ref. No. 10/H0722/34).

Conflict of interest: None declared. 


\section{Appendix 1a. The Chelsea Critical Care Physical Assessment Tool}

\begin{tabular}{|c|c|c|c|c|c|c|}
\hline Aspect of physicality & Level 0 & Level 1 & Level 2 & Level 3 & Level 4 & Level 5 \\
\hline Respiratory function & $\begin{array}{l}\text { Complete ventilator } \\
\text { dependence. } \\
\text { Mandatory breaths } \\
\text { only. May be fully } \\
\text { sedated/ paralysed }\end{array}$ & $\begin{array}{l}\text { Ventilator } \\
\text { dependence. } \\
\text { Mandatory breaths } \\
\text { with some } \\
\text { spontaneous effort }\end{array}$ & $\begin{array}{l}\text { Spontaneously } \\
\text { breathing with } \\
\text { continuous invasive } \\
\text { or non-invasive } \\
\text { ventilatory support }\end{array}$ & $\begin{array}{l}\text { Spontaneously } \\
\text { breathing with } \\
\text { intermittent invasive } \\
\text { or non-invasive } \\
\text { ventilatory support } \\
\text { or continuous high } \\
\text { flow oxygen (>15 I) }\end{array}$ & $\begin{array}{l}\text { Receiving standard } \\
\text { oxygen therapy }(<15 \\
\text { I) }\end{array}$ & $\begin{array}{l}\text { Self-ventilating with } \\
\text { no oxygen therapy }\end{array}$ \\
\hline Cough & $\begin{array}{l}\text { Absent cough, may } \\
\text { be fully sedated or } \\
\text { paralysed }\end{array}$ & $\begin{array}{l}\text { Cough stimulated } \\
\text { on deep suctioning } \\
\text { only }\end{array}$ & $\begin{array}{l}\text { Weak ineffective } \\
\text { voluntary cough, } \\
\text { unable to clear } \\
\text { independently (e.g. } \\
\text { requires deep } \\
\text { suction) }\end{array}$ & $\begin{array}{l}\text { Weak, partially } \\
\text { effective voluntary } \\
\text { cough, sometimes } \\
\text { able to clear } \\
\text { secretions (e.g. } \\
\text { requires Yankauer } \\
\text { suctioning) }\end{array}$ & $\begin{array}{l}\text { Effective cough, } \\
\text { clearing secretions } \\
\text { with airways } \\
\text { clearance } \\
\text { techniques }\end{array}$ & $\begin{array}{l}\text { Consistent effective } \\
\text { voluntary cough, } \\
\text { clearing secretions } \\
\text { independently }\end{array}$ \\
\hline $\begin{array}{l}\text { Moving within the } \\
\text { bed (e.g. rolling) }\end{array}$ & $\begin{array}{l}\text { Unable, maybe fully } \\
\text { sedated/ paralysed }\end{array}$ & $\begin{array}{l}\text { Initiates movement. } \\
\text { Requires assistance } \\
\text { of two or more } \\
\text { people (maximal) }\end{array}$ & $\begin{array}{l}\text { Initiates movement. } \\
\text { Requires assistance } \\
\text { of at least one } \\
\text { person (moderate) }\end{array}$ & $\begin{array}{l}\text { Initiates movement. } \\
\text { Requires assistance } \\
\text { of one person } \\
\text { (minimal) }\end{array}$ & $\begin{array}{l}\text { Independent in } \geq 3 \\
\text { seconds }\end{array}$ & $\begin{array}{l}\text { Independent in }<3 \\
\text { seconds }\end{array}$ \\
\hline $\begin{array}{l}\text { Supine to sitting on } \\
\text { the edge of the bed }\end{array}$ & $\begin{array}{l}0.9920 .899 \text { to } \\
1.000 \text { Dynamic } \\
\text { Unable/unstable }\end{array}$ & $\begin{array}{l}\text { Initiates movement. } \\
\text { Requires assistance } \\
\text { of two or more } \\
\text { people (maximal) }\end{array}$ & $\begin{array}{l}\text { Initiates movement. } \\
\text { Requires assistance } \\
\text { of at least one } \\
\text { person (moderate) }\end{array}$ & $\begin{array}{l}\text { Initiates movement. } \\
\text { Requires assistance } \\
\text { of one person } \\
\text { (minimal) }\end{array}$ & $\begin{array}{l}\text { Independent in } \geq 3 \\
\text { seconds }\end{array}$ & $\begin{array}{l}\text { Independent in }<3 \\
\text { seconds }\end{array}$ \\
\hline $\begin{array}{l}\text { Dynamic sitting (i.e. } \\
\text { when sitting on the } \\
\text { edge of the } \\
\text { bed/unsupported } \\
\text { sitting) }\end{array}$ & Unable/unstable & $\begin{array}{l}\text { Requires assistance } \\
\text { of two or more } \\
\text { people (maximal) }\end{array}$ & $\begin{array}{l}\text { Requires assistance } \\
\text { of at least one } \\
\text { person (moderate) }\end{array}$ & $\begin{array}{l}\text { Requires assistance } \\
\text { of one person } \\
\text { (minimal) }\end{array}$ & $\begin{array}{l}\text { Independent with } \\
\text { some dynamic } \\
\text { sitting balance (i.e. } \\
\text { able to alter trunk } \\
\text { position within base } \\
\text { of support) }\end{array}$ & $\begin{array}{l}\text { Independent with } \\
\text { full dynamic sitting } \\
\text { balance (i.e. able to } \\
\text { reach out of base of } \\
\text { support) }\end{array}$ \\
\hline Standing balance & $\begin{array}{l}\text { Unable/unstable/be } \\
\text { dbound }\end{array}$ & Tilt table or similar & $\begin{array}{l}\text { Standing hoist or } \\
\text { similar }\end{array}$ & $\begin{array}{l}\text { Dependant on } \\
\text { frame, crutches or } \\
\text { similar }\end{array}$ & $\begin{array}{l}\text { Independent without } \\
\text { aids }\end{array}$ & $\begin{array}{l}\text { Independent without } \\
\text { aids and full } \\
\text { dynamic standing } \\
\text { balance (i.e. able to } \\
\text { reach out of base of } \\
\text { support) }\end{array}$ \\
\hline $\begin{array}{l}\text { Sit to stand (starting } \\
\text { position: } \geq 90^{\circ} \\
\text { hip flexion) }\end{array}$ & Unable/unstable & $\begin{array}{l}\text { Sit to stand with } \\
\text { maximal assistance } \\
\text { (standing hoist or } \\
\text { similar) }\end{array}$ & $\begin{array}{l}\text { Sit to stand with } \\
\text { moderate } \\
\text { assistance (e.g. one } \\
\text { or two people) }\end{array}$ & $\begin{array}{l}\text { Sit to stand with } \\
\text { minimal assistance } \\
\text { (e.g. one person) }\end{array}$ & $\begin{array}{l}\text { Sit to stand } \\
\text { independently } \\
\text { pushing through } \\
\text { arms of the chair }\end{array}$ & $\begin{array}{l}\text { Sit to stand } \\
\text { independently } \\
\text { without upper limb } \\
\text { involvement. }\end{array}$ \\
\hline $\begin{array}{l}\text { Transferring from } \\
\text { bed to chair }\end{array}$ & Unable/unstable & Full hoist & $\begin{array}{l}\text { Standing hoist or } \\
\text { similar }\end{array}$ & $\begin{array}{l}\text { Pivot transfer (no } \\
\text { stepping) with } \\
\text { mobility aid or } \\
\text { physical assistance }\end{array}$ & $\begin{array}{l}\text { Stand and step } \\
\text { transfer with mobility } \\
\text { aid or physical } \\
\text { assistance }\end{array}$ & $\begin{array}{l}\text { Independent } \\
\text { transfer without } \\
\text { equipment }\end{array}$ \\
\hline Stepping & Unable/unstable & $\begin{array}{l}\text { Using a standing } \\
\text { hoist or similar }\end{array}$ & $\begin{array}{l}\text { Using mobility aids } \\
\text { and assistance of at } \\
\text { least one person } \\
\text { (moderate) }\end{array}$ & $\begin{array}{l}\text { Using mobility aid } \\
\text { and assistance of } \\
\text { one person } \\
\text { (minimal) }\end{array}$ & $\begin{array}{l}\text { Using mobility aid or } \\
\text { assistance of one } \\
\text { person (minimal) }\end{array}$ & $\begin{array}{l}\text { Independent without } \\
\text { aid }\end{array}$ \\
\hline $\begin{array}{l}\text { Grip strength } \\
\text { (predicted mean for } \\
\text { age and gender on } \\
\text { the strongest hand) }\end{array}$ & Unable to assess & $<20 \%$ & $<40 \%$ & $<60 \%$ & $<80 \%$ & $\geq 80 \%$ \\
\hline
\end{tabular}

Please cite this article in press as: Corner EJ, et al. The Chelsea Critical Care Physical Assessment Tool (CPAx): validation of an innovative new tool to measure physical morbidity in the general adult critical care population; an observational proof-of-concept pilot study. Physiotherapy (2012), doi:10.1016/j.physio.2012.01.003 


\begin{tabular}{|c|c|c|c|c|c|c|c|c|c|c|c|c|c|c|}
\hline \multirow[t]{2}{*}{$\begin{array}{c}\text { Age } \\
\text { (years) }\end{array}$} & \multicolumn{7}{|c|}{ Men } & \multicolumn{7}{|c|}{ Women } \\
\hline & Hand & Mean & $<20 \%$ & $<40 \%$ & $<60 \%$ & $<80 \%$ & $\geq 80 \%$ & Hand & Mean & $<20 \%$ & $<40 \%$ & $<60 \%$ & $<80 \%$ & $\geq 80 \%$ \\
\hline \multirow{2}{*}{$\begin{array}{c}15 \text { to } \\
19\end{array}$} & $\mathrm{R}$ & 46.91 & 9.38 & 18.76 & 28.15 & 37.53 & 37.53 & $\mathrm{R}$ & 28.82 & 5.76 & 11.53 & 17.29 & 23.06 & 23.06 \\
\hline & $\mathrm{L}$ & 42.13 & 8.43 & 16.85 & 25.28 & 33.70 & 33.70 & $\mathrm{~L}$ & 24.98 & 5.00 & 9.99 & 14.99 & 19.98 & 19.98 \\
\hline \multirow{2}{*}{$\begin{array}{l}20 \text { to } \\
24\end{array}$} & $\mathrm{R}$ & 48.15 & 9.63 & 19.26 & 28.89 & 38.52 & 38.52 & $\mathrm{R}$ & 28.33 & 5.67 & 11.33 & 17.00 & 22.66 & 22.66 \\
\hline & $\mathrm{L}$ & 43.08 & 8.62 & 17.23 & 25.85 & 34.46 & 34.46 & $\mathrm{~L}$ & 25.78 & 5.16 & 10.31 & 15.47 & 20.62 & 20.62 \\
\hline \multirow{2}{*}{$\begin{array}{l}25 \text { to } \\
29\end{array}$} & $\mathrm{R}$ & 53.76 & 10.75 & 21.50 & 32.26 & 43.01 & 43.01 & $\mathrm{R}$ & 33.82 & 6.76 & 13.53 & 20.29 & 27.06 & 27.06 \\
\hline & L & 48.60 & 9.72 & 19.44 & 29.16 & 38.88 & 38.88 & $\mathrm{~L}$ & 30.31 & 6.06 & 12.12 & 18.19 & 24.25 & 24.25 \\
\hline \multirow{2}{*}{$\begin{array}{c}30 \text { to } \\
34\end{array}$} & $\mathrm{R}$ & 52.63 & 10.53 & 21.05 & 31.58 & 42.10 & 42.10 & $\mathrm{R}$ & 33.97 & 6.79 & 13.59 & 20.38 & 27.18 & 27.18 \\
\hline & $\mathrm{L}$ & 48.98 & 9.80 & 19.59 & 29.39 & 39.18 & 39.18 & $\mathrm{~L}$ & 31.64 & 6.33 & 12.66 & 18.98 & 25.31 & 25.31 \\
\hline \multirow{2}{*}{$\begin{array}{c}35 \text { to } \\
39\end{array}$} & $\mathrm{R}$ & 53.16 & 10.63 & 21.26 & 31.90 & 42.53 & 42.53 & $\mathrm{R}$ & 32.46 & 6.49 & 12.98 & 19.48 & 25.97 & 25.97 \\
\hline & $\mathrm{L}$ & 51.75 & 10.35 & 20.70 & 31.05 & 41.40 & 41.40 & $\mathrm{~L}$ & 29.77 & 5.95 & 11.91 & 17.86 & 23.82 & 23.82 \\
\hline \multirow{2}{*}{$\begin{array}{c}40 \text { to } \\
44\end{array}$} & $\mathrm{R}$ & 55.49 & 11.10 & 22.20 & 33.29 & 44.39 & 44.39 & $\mathrm{R}$ & 30.34 & 6.07 & 12.14 & 18.20 & 24.27 & 24.27 \\
\hline & $\mathrm{L}$ & 50.40 & 10.08 & 20.16 & 30.24 & 40.32 & 40.32 & $\mathrm{~L}$ & 26.23 & 5.25 & 10.49 & 15.74 & 20.98 & 20.98 \\
\hline \multirow{2}{*}{$\begin{array}{l}45 \text { to } \\
49\end{array}$} & $\mathrm{R}$ & 49.93 & 9.99 & 19.97 & 29.96 & 39.94 & 39.94 & $\mathrm{R}$ & 35.30 & 7.06 & 14.12 & 21.18 & 28.24 & 28.24 \\
\hline & $\mathrm{L}$ & 48.94 & 9.79 & 19.58 & 29.36 & 39.15 & 39.15 & $\mathrm{~L}$ & 32.06 & 6.41 & 12.82 & 19.24 & 25.65 & 25.65 \\
\hline \multirow{2}{*}{$\begin{array}{c}50 \text { to } \\
54\end{array}$} & $\mathrm{R}$ & 48.40 & 9.68 & 19.36 & 29.04 & 38.72 & 38.72 & $\mathrm{R}$ & 28.37 & 5.67 & 11.35 & 17.02 & 22.70 & 22.70 \\
\hline & $\mathrm{L}$ & 41.46 & 8.29 & 16.58 & 24.88 & 33.17 & 33.17 & $\mathrm{~L}$ & 26.28 & 5.26 & 10.51 & 15.77 & 21.02 & 21.02 \\
\hline \multirow{2}{*}{$\begin{array}{c}55 \text { to } \\
59\end{array}$} & $\mathrm{R}$ & 45.71 & 9.14 & 18.28 & 27.43 & 36.57 & 36.57 & $\mathrm{R}$ & 29.76 & 5.95 & 11.90 & 17.86 & 23.81 & 23.81 \\
\hline & $\mathrm{L}$ & 42.16 & 8.43 & 16.86 & 25.30 & 33.73 & 33.73 & $\mathrm{~L}$ & 27.81 & 5.56 & 11.12 & 16.69 & 22.25 & 22.25 \\
\hline \multirow{2}{*}{$\begin{array}{c}60 \text { to } \\
64\end{array}$} & $\mathrm{R}$ & 40.59 & 8.12 & 16.24 & 24.35 & 32.47 & 32.47 & $\mathrm{R}$ & 26.35 & 5.27 & 10.54 & 15.81 & 21.08 & 21.08 \\
\hline & $\mathrm{L}$ & 37.25 & 7.45 & 14.90 & 22.35 & 29.80 & 29.80 & $\mathrm{~L}$ & 23.47 & 4.69 & 9.39 & 14.08 & 18.78 & 18.78 \\
\hline \multirow{2}{*}{$\begin{array}{c}65 \text { to } \\
69\end{array}$} & $\mathrm{R}$ & 40.87 & 8.17 & 16.35 & 24.52 & 32.70 & 32.70 & $\mathrm{R}$ & 23.60 & 4.72 & 9.44 & 14.16 & 18.88 & 18.88 \\
\hline & $\mathrm{L}$ & 36.57 & 7.31 & 14.63 & 21.94 & 29.26 & 29.26 & $\mathrm{~L}$ & 23.38 & 4.68 & 9.35 & 14.03 & 18.70 & 18.70 \\
\hline \multirow{2}{*}{$\begin{array}{c}70 \text { to } \\
74\end{array}$} & $\mathrm{R}$ & 37.48 & 7.50 & 14.99 & 22.49 & 29.98 & 29.98 & $\mathrm{R}$ & 25.84 & 5.17 & 10.34 & 15.50 & 20.67 & 20.67 \\
\hline & $\mathrm{L}$ & 35.49 & 7.10 & 14.20 & 21.29 & 28.39 & 28.39 & $\mathrm{~L}$ & 22.92 & 4.58 & 9.17 & 13.75 & 18.34 & 18.34 \\
\hline \multirow[b]{2}{*}{$75+$} & $\mathrm{R}$ & 32.76 & 6.55 & 13.10 & 19.66 & 26.21 & 26.21 & $\mathrm{R}$ & 19.40 & 3.88 & 7.76 & 11.64 & 15.52 & 15.52 \\
\hline & $\mathrm{L}$ & 28.59 & 5.72 & 11.44 & 17.15 & 22.87 & 22.87 & $\mathrm{~L}$ & 17.64 & 3.53 & 7.06 & 10.58 & 14.11 & 14.11 \\
\hline
\end{tabular}

Table developed from normal UK hand grip strength values in Gilbertson L, Barber-Lomax S. Power and pinch grip strength recorded using the hand-held Jamar dynamometer and B + L hydraulic pinch gauge: British normative data for adults. Br J Occupat Ther 1994;57:483-8.

\section{Appendix 1b. The Chelsea Critical Care Physical Assessment Tool}

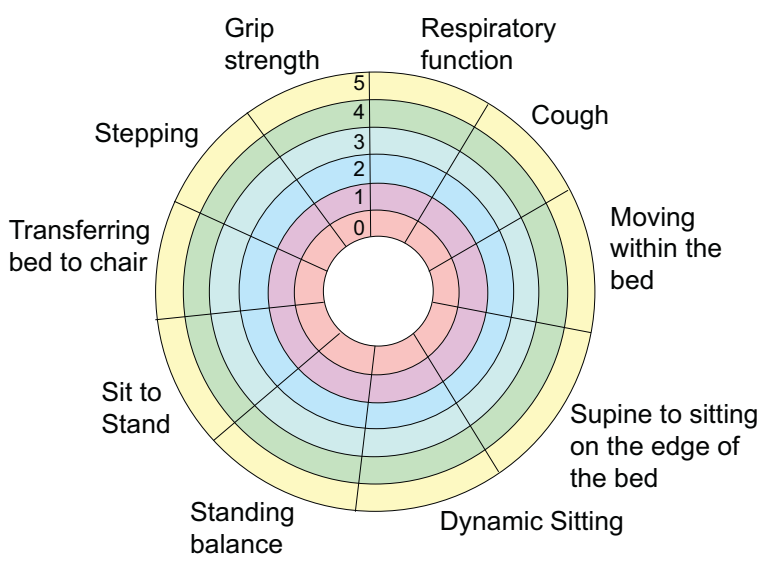

\section{References}

[1] Dincer EH. How should we deal with muscle weakness in critically ill patients? Crit Care Med 2009;37:2648-9.

[2] Winkelman C. Bed rest in health and critical illness. AACN Adv Crit Care 2009;20:254-66.

[3] Griffiths R, Hall J. Intensive care unit-acquired weaknesses. Crit Care Med 2010;38:779-87.
[4] Hermans G, De Jonge B, Bruyninckx F, Van de Berghe G. Clinical review: critical illness polyneuropathy and myopathy. Crit Care 2008;12(238), doi:10.1186/cc7100.

[5] National Institute of Clinical Excellence. Rehabilitation after critical illness. London: NICE; 2009. Available at: www.nice.org.uk, Last accessed: 29/02/2012.

[6] Collen FM, Wade DT, Robb GF, Bradshaw CM. The Rivermead Mobility Index: a further development of the Rivermead Motor Assessment. Int Disabil Stud 1991;13:50-4.

[7] Fan E, Ciesla ND, Truong AD, Bhoopathu V, Zeger SL, Needham DM. Inter-rater reliability of manual muscle strength testing in ICU survivors and simulated patients. Intens Care Med 2010;36:1038-43.

[8] Black NA, Jenkinson C, Hayes JA, Young JD, Vella K, Rowan KM, et al. Review of outcome measures used in adult critical Care. Crit Care Med 2001;29:2119-24.

[9] Hayes JA, Black NA, Jenkinson C, Young JD, Rowan KM, Daly K, et al. Outcome measures for adult critical care: a systematic review. Health Technol Assess 2000;4:1-111.

[10] Skinner EH, Berney S, Warrilow S, Denehy L. Development of an outcome measure (the PFIT): an pilot exercise training protocol for use in intensive care. Crit Care Resusc 2009;11:110-5.

[11] DiCicco J, Whalen D. University of Rochester Acute Care Evaluation: development of a new functional outcome measure for the acute care setting. J Acute Care Phys Ther 2010;1:14-20.

[12] Streiner DL, Norman GR. Health measurement scales: a practical guide to their development and use. 4th edn. New York: Oxford University Press; 2008.

[13] NHS employers. National Profiles for Physiotherapy; 2005. Last accessed: 28/02/2012 http://www.nhsemployers.org/ PayAndContracts/AgendaForChange/NationalJobProfiles/Documents/ Physiotherapy.pdf.

[14] Polit DF, Tatano Beck C, Owen SV. Is the CVI an acceptable indicator of content validity? Appraisal and recommendations. Res Nurs Health 2007;30:459-67. 
PHYST-637; No. of Pages 9

E.J. Corner et al. / Physiotherapy xxx (2012) xxx-xxx

9

[15] Lynn MR. Determination and quantification of content validity. Nurs Res 1986;35:382-6.

[16] Gao ZJ, Quin YZA. Study of cough peak expiratory flow in predicting extubation outcome. Chin Crit Care Med 2009;21:390-3.

[17] Perry A, Morris M, Unsworth C, Bucket S, Skat J, Bod K, et al. Therapy outcome measures for allied health practitioners in Australia: the CusTOMs. Int J Qua Health Care 2004;16:285-91.

[18] Unsworth C, Bucket S, Duncombe D, Perry A, Skean J, Thyfor N. Validity of the CusTOM scales: a comparison of the AusTOMs and EuroQol-5D. Health Qua Life Outcomes 2004;2, doi:10.1186/1477-7525-2-6.

[19] Ali NA, O'Brien JM, Hoffman SP, Philips G, Garland A, Finlay JCW, et al. Acquired weakness, handgrip strength, and mortality in critically ill patients. Am J Resp Crit Care Med 2008;178:261-8.

[20] Callahan L, Supinski G. Sepsis-induced myopathy. Crit Care Med 2009;37(Suppl.):S354-67.
[21] Bigatello LM, Stelfoc HT, Berra L, Schmidt U, Gish I, Getting E. Outcome of patients undergoing prolonged mechanical ventilation after critical illness. Crit Care Med 2007;35:2491-7.

[22] Garret AM, Ruta DA, Abdalla MI, Buckingham JK, Russell IT. The SF 36 health survey questionnaire: an outcome measure suitable for routine use within the NHS? BMJ 1993;306:1440-4.

[23] de Rooji SE, Ahbu-Hanna A, Levi M, de Jonge E. Factors that predict outcome of intensive care treatment in very elderly patients: a review. Crit Care 2009;9:R307-14.

[24] Marik P. Palliative care in ICU: should age limit admission to the intensive care unit? Am J Hospices Palliate Med 2007;24: 63-6.

[25] Lavine S, Nguyen T, Taylor N, Friscia M, Budak M, Rothenberg P, et al. Rapid disuse atrophy of the diaphragm fibers in mechanically ventilated humans. N Engl J Med 2008;358:132-5.

Available online at www.sciencedirect.com

SciVerse ScienceDirect

Please cite this article in press as: Corner EJ, et al. The Chelsea Critical Care Physical Assessment Tool (CPA): validation of an innovative new tool to measure physical morbidity in the general adult critical care population; an observational proof-of-concept pilot study. Physiotherapy (2012), doi:10.1016/j.physio.2012.01.003 